\title{
Effect of International Entrepreneurial Orientation on the Internationalization of SMEs: The Contingent Effect of Export Promotion Programs
}

\author{
Ahmed Ibrahim Karage ${ }^{1}$, Raja Nerina Raja Yusof ${ }^{2}$, \& Devika Nadarajah ${ }^{3}$ \\ ${ }^{1}$ Faculty of Social and Management Sciences, Yobe State University, Nigeria \\ ${ }^{2}$ School of Business and Economics, Universiti Putra Malaysia, Malaysia \\ ${ }^{3}$ Putra Business School, Malaysia \\ Correspondence: Raja Nerina Raja Yusof, School of Business and Economics, Universiti Putra Malaysia, \\ Malaysia.
}

Received: October 20, 2021

doi:10.5539/ibr.v14n12p160
Accepted: November 15, $2021 \quad$ Online Published: November 25, 2021

URL: https://doi.org/10.5539/ibr.v14n12p160

\begin{abstract}
The study argues that the role of export promotion programs (EPPs) is indirectly exhibited by enhancing the influence of managerial and organizational resources on the internationalization of SMEs. This study proposes that the dimensions of international entrepreneurial orientation (innovativeness, pro-activeness and risk-taking) will show varied strengths as predictors of the internationalization of SMEs' with the influence of EPPs. Using structural equation modeling, data collected from 266 exporting SMEs in Nigeria were analyzed and it is concluded that SMEs' risk-taking in internationalization increases with participation in EPPs. Similarly, there was an increase in innovativeness among internationalizing SMEs with increased participation in EPPs. Finally, participation in EPPs did not show any impact in pro-activeness attribute towards internationalization of SMEs. This study demonstrates the supportive role of institutions in SMEs' managerial capacity building in overcoming internationalization challenges by developing the culture of risk taking and innovativeness.
\end{abstract}

Keywords: Internationalization of SMEs, export promotion programs, international entrepreneurial orientation, innovativeness, pro-activeness, risk-taking.

\section{Introduction}

Rapid growth of international SMEs symbolizes its importance and role in international trade transactions. This study focuses on the influence of export promotion programs (EPPs) in moderating international entrepreneurial orientation (IEO) dimensions as antecedents to the internationalization of SMEs. Previous literature reviews show that the discussion of entrepreneurship scholars on EPPs have mainly been drivers of organizational resources (Leonidou, Palihawadana, \& Theodosiou, 2011) and their effects on export performance (Durmu, Apfelthaler, Zamantili, Alvarez, \& Mughan, 2012: Gençtürk, \& Kotabe, 2001: Sraha \& Sraha, 2015). Such studies mostly focus on direct estimation of entrepreneurial orientation (EO) dimensions and performance of firms (Kuivalainen, Sundqvist, \& Servais, 2007; Ajayi, 2016). This shows that previous studies paid little attention to the EPPs' influence on managerial resources of a firm in strengthening them for international competitiveness. To bridge this gap, the current study discusses the moderating effects of EPPs on each of the dimensions of IEO to show how they enhance firms' capacity for successful and efficient internationalization. Furthermore, this study provides an overview of related literature to show evidences from previous studies on the importance of IEO in achieving internationalization of SMEs, and the influence of EPPs on the dimensions of IEO in developing a firm's international potential in value creation. The paper begins with a discussion of internationalization of SMEs, international entrepreneurial orientation and its influence on SMEs' internationalization. The study further discusses EPPs' impacts on the dimensions of IEO through a moderation effect on internationalization of SMEs. Discussion of implications for theory, industry and policy were also presented.

\section{Literature Review}

INTERNATIONALIZATION OF SMES 
Theory of internationalization asserts that internationalization is a process involving development of business relationships in a network for international transactions through the attitude of management (Johanson, 1990; Mbura \& Rutashobya, 2004) which subsequently impact on export performance. Johanson and Vahlne (1977) and Daszkiewicz and Wach (2012) affirm that internationalization is any sort of undertaking involving cross-border activities of firms, indicating entrepreneurship potential of a firm in "identification and exploitation of entrepreneurial opportunities" with a focus on innovation, newness and value creation. Thus, international entrepreneurship is conceptualized as "the discovery, evaluation and exploitation of opportunities - across national borders - to create future goods and services" (Oviatt \& Mcdougall, 2005).

\section{INTERNATIONAL ENTREPRENEURIAL ORIENTATION (IEO)}

Scholars in the field of international entrepreneurship paid attention on IEO as a potential driver for expanding international market (Coviello, Mcdougall, \& Oviatt, 2011; Covin \& Miller, 2013;Dai, Maksimov, Gilbert, \& Fernhaber, 2014). IEO is the central strategic pose of firms competing in foreign markets, and are attributes that help in overcoming constraints in the process of internationalization (Jones \& Coviello, 2005). Entrepreneurial orientation (EO) explains the ability of a firm to be innovative, risk taking and proactive in trying new things (Khalili, Nejadhussein, \& Fazel, 2013). IEO is very essential in attaining foreign market success through aligning factors that are internal and external to the firm (Hermannsdottir, 2008).

Covin and Miller (2014) stated that "IEO is treated as a construct the same as EO". The 'international' reflects the context that EO studies are undertaken. Knight (2001) identified three-dimensional IEO as the major success factor determining the international performance of the firm. Greater number of empirical studies used the EO scale proposed by Miller (2011) measuring three dimensions of EO. Lumpkin and Dess (1996) found that various levels of the three dimensions can equally shape $\mathrm{EO}$ of a given firm.

\section{DIMENSIONS OF IEO}

Covin and Miller (2013b) identified the dimensions of IEO as consisting of international product innovativeness, international market-specific risk-taking and pro-activeness to exploit opportunities in international markets and be aggressive on competitors in international markets. The current study, however, focuses on the three IEO dimensions - international pro-activeness, international innovativeness, and international risk-taking (Covin \& Sleven, 1989; Miller \& Breton-Miller, 2011) - and the examination of moderating effects of EPPs relating to each of the IEO dimensions on internationalization of SMEs.

\section{EXPORT PROMOTION PROGRAMS (EPPs)}

Government and policy makers around the world engage in strategies of promoting export in an effort to boost national economic development to attain global competitiveness (Griffith \& Czinkota, 2012) and to also enhance domestic firms' international competitiveness (Lages \& Montgomery, 2015). Therefore, governments design a range of programs to offer export support to SMEs to trigger growth of an economy (Ali \& Shamsuddoha, 2012). In most controlled economies, institutions have an important role in the process of internationalization of firms (North, 2016; Sun, Peng, Lee, \& Tan, 2015) through programs such as EPPs.

Institutional theory suggests that government agencies are supportive to firms by engaging them in programs such as EPPs to enhance firms' performance in internationalization (Kibler \& Kautonen, 2016; Sambharya \& Musteen, 2014; Szyliowicz \& Galvin, 2010). External resource such as government EPPs could be a means for firms' resources acquisition for export competitiveness. Government EPPs enable firms to acquire competencies, skills and export knowledge which will subsequently enhance the perception of management, their commitment and attitude which ultimately influence the performance of firm and export strategy (Haddoud, Jones, \& Newbery, 2017; Jones \& Newbery, 2017; Shamsuddoha \& Ali, 2006). EPPs are kinds of favorable policies and assistance which make SMEs realize an effective production process for global market competitiveness.

In this study, EPPs are considered as a proxy for institutional influence in enhancing the capacity of SMEs to export by strengthening their entrepreneurial orientation. Thus, EPPs are influential in enhancing capabilities and resources of an organization and consequently contribute to performance in export (Leonidou et al., 2011; Ali. \& Shamsuddoha, 2012). The next paragraph discusses the effect of EPPs on specific dimensions of IEO.

\section{Hypotheses Development}

\section{INFLUENCE OF EPPS ON THE DIMENSIONS OF IEO}

The dimensions of IEO in this study consist of international innovativeness, international pro-activeness and international risk-taking. They are discussed below together with specific components of EPPs that enhance them. 


\section{INTERNATIONAL INNOVATIVENESS}

International innovativeness is a firm's inclination to offer new developed products or services in international markets (Balabanis \& Katsikea; Boso, Story, Cadoan \& Ashie, 2015). International innovativeness also explains the intensity of innovation in production and launching of new products in international markets. EPPs provide opportunities for firms to develop their innovativeness in international markets through network development with local firms and institutions by enhancing entrepreneurial orientation (Owusu-frimpong \& Martins, 2010). These opportunities are embedded in the program components that are developed purposely to enhance innovation capacity of entrepreneurs. Kaleka (2002) and Morgan et al., (2006) opined that adoption of new approaches and concepts in the process of production, development of products that are innovative for international markets, commencing innovative marketing methods and techniques are the skills required by entrepreneurs to be innovative in international markets. Once such EPPs components are successfully delivered to firms, their ability to develop international innovative capabilities will be achieved. Thus, the study argues that basic skills that firms can receive from EPPs are new ideas and techniques in the process of production, innovation in export marketing, detecting trends of competitors' new ideas, and innovations in export marketing. Therefore, the following hypothesis is proposed:

$\mathrm{H}_{1}$. The relationship between international innovativeness and internationalization of SMEs will be stronger with participation in export promotion programs.

\section{INTERNATIONAL PRO-ACTIVENESS}

International pro-activeness is a firm's inclination to identify and exploit opportunities in international markets ahead of competitors in the foreign market (Knight, 2001; Sundqvist, Kyläheiko, Kuivalainen \& Cadogan, 2012). Thus, the government role as a change agent supports firms by facilitating their ability to be more pro-active and have well-planned exporting techniques (Leonidou et al., 2011). Managerial, production/research and development and intellectual resources (Kaleka, 2002: Morgan, Vorhies \& Schlegelmilch, 2006) enable entrepreneurs' to possess better attitude towards foreign markets. Pro-activeness is realized by developing various skills provided in the EPPs components by enhancing managerial resources, commitment, and technology and export requirement skills. SMEs that benefit from EPPs are more pro-active in attaining internationalization. Hence the following hypothesis is formulated:

$\mathrm{H}_{2}$ : The relationship between international pro-activeness and internationalization of SMEs will be stronger with participation in EPPs.

\section{INTERNATIONAL RISK-TAKING}

International risk-taking is the tendency of a firm to involve in foreign market transactions in an uncertain situation (Covin \& Miller, 2013b). The aim of EPPs is to reduce negative perception of international risk, cost and associated complexities regarding export (Leaonidou et al., 2011). Assistance offered to exporting domestic firms gives them an opportunity to be involved in foreign market networks to enhance their international business development (Owusu-Frimpong \& Martins, 2010). Moreover, such assistance from EPPs creates open, partnered or networked innovation in which network members' pool knowledge resources and share innovation risks. Furthermore, information provided by EPPs enhances firms' knowledge about the destination country's culture which minimizes risk arising from cultural conflicts with foreign distributors (Haddoud, Jones \& Newbery, 2017). Hence information is crucial for exporting firms to reduce foreign market uncertainties (Leonidou \& Theodosiou, 2004) and as such, EPPs' information enables firms to manage risk more effectively. Based on these assertions, the following hypothesis is formulated:

$\mathrm{H}_{3}$ : The relationship between international risk-taking and internationalization of SMEs will be stronger with participation in EPPs.

\section{Research Methods}

The researchers designed a quantitative study and collected data by means of survey questionnaires from entrepreneurs of exporting SMEs in Nigeria. The procedure for measuring instruments used and sampling techniques are discussed as follows.

\section{MEASURES}

A seven-point Likert scale questionnaire was utilized for the collection of data for all the constructs of the study. The instruments used were sourced from previous studies and were adapted to measure internationalization of SMEs in Nigeria. The construction of the questionnaire was based on previous studies such as Felzensztein, Ciravegna, Robson and Amorós, (2015) and Knight, Kim and Knight, (2015) who also used multiple items 
measurement scale (see Appendix). Five managers were selected to pre-test the questionnaire to provide an assessment of its face validity. Slight modifications in wordings were done based on the observations and inputs received.

\section{INTERNATIONAL ENTREPRENEURIAL ORIENTATION (IEO)}

Entrepreneurial orientation of a firm explains a firm's attributes in engaging in innovativeness, undertake fairly risky ventures and involvement in proactive innovations (Khalili et al., 2013).This measure is adopted from the work of Covin and Sleven (1989) with a total of nine (9) items. Entrepreneurs were requested to evaluate to what level they agree or disagree with the items with regard to their entrepreneurial activities and perceptions of foreign markets. It measures how a firm is proactive and aggressive in pursuing an opportunity in international markets and is associated with managerial vision, innovativeness, risk taking and pro-active competitive positions.

\section{INTERNATIONALIZATION OF SMEs (ISMEs)}

Percentage of international sale to total sale is the most regularly used measurement to capture international performance effectiveness (Yoeh, 2004). It has been a viable proxy for degree of internationalization (Kumar \& Singh, 2008).

\section{EXPORT PROMOTION PROGRAMs (EPPs)}

Export Promotion Programs (EPPs) adopted a scale developed by Leonidou et al., (2011). Ten items were used with a seven (7) point scale having options of $1=$ "not adopted" to $7=$ "fully adopted". It measures ways of establishing network and enhancing contact activities such as trade fairs in foreign markets, by providing export counseling to support SMEs' inadequate experience on international markets and through assisting SMEs in arranging visits to enable managers connect with other stakeholders (networks) abroad.

\section{DATA COLLECTION AND SAMPLE}

The data for this study was obtained from the Nigerian exporting SMEs listed in the Nigerian Export Promotion Council (NEPC), a database of exporting businesses in Nigeria. The researchers administered questionnaires in track with earlier studies on network and knowledge acquisition (Simonin, 1997). CEOs of SMEs were the main source of information for the study. It was based on the assumption that CEOs can provide information about their firms better. However this study provides for the subordinate of the CEO to respond on the CEO's directives. Consent letters stating the research aims with assurance of respondents' anonymity were mailed or dispatched to the CEOs of the 529 targeted SMEs; however, one hundred and twelve (112) letters returned undelivered. The researchers therefore emailed the questionnaires to the remaining potential respondent firms with the option of filling the questionnaires online via prepared Google form. A follow-up letter was sent after two weeks and subsequently again with another follow-up letter after another two weeks. Total of 272 responses were received, representing $65 \%$ response rate. Six firms were excluded from the data file because of significant missing data, more than 15\% (Joseph F. Hair, Hult, Ringle, \& Rstedt, 2017). This gave the study a final sample of 266 SMEs.

The profiles of the exporting SMEs in Table 1 show that $41 \%$ are involved in manufactured goods followed by petrochemicals with $21 \%$ and rubber and gum was $10 \%$. The SMEs that generate employment for 11-50 people were $47 \%$, up to 10 people was $38 \%$ and only $1 \%$ of the SMEs provide employment to more 200 people. The ownership structure reveals that $41 \%$ were partnership businesses, $31 \%$ limited liability and $28 \%$ were sole proprietors. The exporting experience was not much because 59\% of the SMEs were having 5 years and less experience. SMEs with 6-14 years were $40 \%$ and those with more than 15 years exporting experience constitute only $1 \%$. Most SMEs export were within Africa, with $41 \%$, those exporting to Europe were $28 \%$. SMEs exporting to America and Asia were $14 \%$ each, and $4 \%$ to Australia.

Table 1. Profile of the respondent firms

\begin{tabular}{ll}
\hline Industry of the Firm & Percentage (\%) \\
\hline Food and drinks & 12 \\
Rubber and gum & 10 \\
Manufactured goods & 41 \\
Solid minerals & 16 \\
Petrochemical and cosmetics & 21 \\
Employment & Percentage (\%) \\
Up to-10 people & 38 \\
$11-50$ people & 47
\end{tabular}




\begin{tabular}{ll} 
51-100 people & 12 \\
$101-150$ People & 5 \\
Above 200 People & 1 \\
Ownership Structure & Percentage (\%) \\
Sole proprietors & 28 \\
Partnership & 41 \\
Limited liability company & 31 \\
Exporting experience & Percentage (\%) \\
Up to 5 years & 59 \\
6-15 years & 40 \\
More than 15 years. & 1 \\
Exporting regions & Percentage (\%) \\
Africa & 41 \\
America & 14 \\
Asia & 14 \\
Australia & 4 \\
Europe & 28 \\
\hline
\end{tabular}

\section{DATA ANALYSIS, INTERPRETATION AND RESULTS}

In analyzing the data, the study employed partial least squares (PLS) technique for analysis with SPLS 3.2.7 software (Ringle \& Sarstedt, 2015). The study tested the measurement model involving reliability and validity measures, followed by the structural model to test the hypothesized relationships (Hair, Sarstedt, Hopkins \& Kuppelwieser, 2014). Bootstrapping was run to test the significance of the loading and the path coefficient. Blindfolding was also tested to determine the model predictive accuracy (Hair et al., 2017).

\section{MEASUREMENT MODEL EVALUATION}

The study examined the measurement model reliability and validity by assessing both composite reliability, convergent and discriminant validities. Discriminant validity explains the extent to which items measure dissimilar concepts from one another and was examined based heterotrait-monotrait (HTMT) ratio. Convergent validity was determined by assessing the average variance extracted (AVE), loadings and composite reliability (Hair et al., 2017). In this study, HTMT ratio values were found to be below the threshold of 0.85 and all the loadings were found to be above 0.7. The composite reliabilities were all above 0.7 and the AVE values were above 0.5 as proposed by Hair et al. (2017) (see Table 2).

Table 2. Convergent Validity

\begin{tabular}{|c|c|c|c|c|}
\hline Constructs & Items & Loadings & AVE & CR \\
\hline \multirow[t]{9}{*}{ Export Promotion Programs } & EPP1 & 0.876 & 0.773 & 0.968 \\
\hline & EPP2 & 0.865 & & \\
\hline & EPP3 & 0.904 & & \\
\hline & EPP4 & 0.896 & & \\
\hline & EPP5 & 0.857 & & \\
\hline & EPP6 & 0.906 & & \\
\hline & EPP7 & 0.86 & & \\
\hline & EPP8 & 0.887 & & \\
\hline & EPP9 & 0.861 & & \\
\hline \multirow[t]{3}{*}{ IEO-Innovativeness } & IEO-INV1 & 0.885 & 0.823 & 0.933 \\
\hline & IEO-INV2 & 0.933 & & \\
\hline & IEO-INV3 & 0.902 & & \\
\hline \multirow[t]{3}{*}{ IEO-Pro-activeness } & IEO-PRO1 & 0.857 & 0.721 & 0.886 \\
\hline & IEO-PRO2 & 0.866 & & \\
\hline & IEO-PRO3 & 0.824 & & \\
\hline \multirow[t]{3}{*}{ IEO-Risk taking } & IEO-RIS1 & 0.861 & 0.732 & 0.891 \\
\hline & IEO-RIS2 & 0.862 & & \\
\hline & IEO-RIS3 & 0.844 & & \\
\hline Internationalization of SMEs & ISME & 1 & 1 & 1 \\
\hline
\end{tabular}

$\mathrm{AVE}=$ Average Variance Extracted, $\mathrm{CR}=$ Composite Reliability

This study assessed the heterotrait-monotrait ratio (HTMT) to examine discriminant validity (Hair et al., 2017). The criterion rate used in assessing the correlation is $0.85\left(\mathrm{HTMT}_{0.85}\right)$ (Henseler, Ringle, \& Sarstedt, 2015). In Table 3 and Figure 1, the HTMT results show that all the correlations are less than 0.85 and therefore 
discriminant validity of the model was established.

Table 3. Hetrotrait-Monotrait (HTMT)

\begin{tabular}{|c|c|c|c|c|c|c|c|c|}
\hline & EPP & EPP*IEO_INV & EPP*IEO_PRO & EPP*IEO_RIS & IEO_INV & IEO_PRO & IEO_RIS & ISME \\
\hline \multicolumn{9}{|l|}{ EPP } \\
\hline EPP*IEO_INV & 0.132 & & & & & & & \\
\hline EPP*IEO_PRO & 0.051 & 0.647 & & & & & & \\
\hline EPP*IEO_RIS & 0.05 & 0.806 & 0.697 & & & & & \\
\hline IEO_INV & 0.239 & 0.449 & 0.457 & 0.416 & & & & \\
\hline IEO_PRO & 0.219 & 0.436 & 0.445 & 0.378 & 0.555 & & & \\
\hline IEO_RIS & 0.323 & 0.436 & 0.416 & 0.274 & 0.813 & 0.754 & & \\
\hline ISME & 0.263 & 0.412 & 0.475 & 0.324 & 0.636 & 0.455 & 0.776 & \\
\hline
\end{tabular}

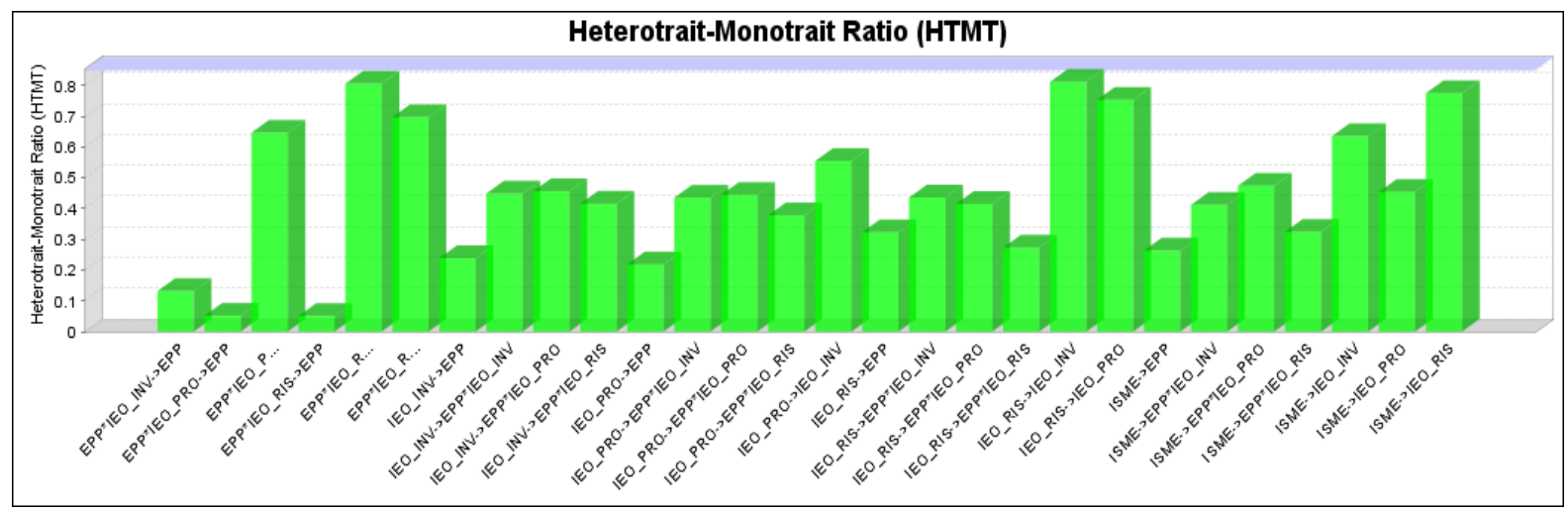

Figure 1. HTMT (Pictorial display)

\section{EVALUATION OF STRUCTURAL MODEL}

Structural model assessment in PLS-SEM involves evaluation of the significance of the path coefficient (t-values) and the level of $\mathrm{R}^{2}$ (Hair et al., 2017). Bootstrapping procedure with 5000 resamples to obtain t-values for determination of significance is to be performed. Besides the basic procedures, it is also required that scholars assess the predictive relevance $\left(\mathrm{Q}^{2}\right)$ as well as effect sizes $\left(\mathrm{f}^{2}\right)$ (Hair, et al. 2017). The current study assessed the moderation effects of EPPs on international entrepreneurial orientation (IEO)'s dimensions as predictors to internationalization of SMEs.

\section{RESULTS}

The result is presented in Figure 2, Figure 3 and Table 4. The $\mathrm{R}^{2}$ was 0.498 suggesting that $49 \%$ variance in internationalization of SMEs could be explained by innovativeness, pro-activeness and risk taking dimensions of IEO. The blindfolding result also shows that $\mathrm{Q}^{2}$ is 0.485 , indicating that the model predictive relevance has been achieved.

The study tested for moderation effect of EPPs on the relationship between dimensions of IEO (Innovativeness, Pro-activeness and Risk taking) and internationalization of SMEs. In testing the three moderation hypotheses, the researchers used two-stage approach, standardized product term generation and automatic weighing mode. The researchers formed the interaction between export promotion programs and each of the IEO dimensions. There was $R^{2}$ increase to 0.534 when the interacting effect was formed, giving an $R^{2}$ change of $3.6 \%$. The interaction effect was found to be significant (negative) for export promotion program and innovativeness $(\beta=0.086 ; t=2.165 ; p<0.03)$ and export promotion program and risk taking $(\beta=0.074 ; t=2.895 ; p<0.004)$. However, there was no significant effect on the interaction between export promotion program and pro-activeness. Therefore, $\mathrm{H}_{1}$ and $\mathrm{H}_{3}$ were supported while $\mathrm{H}_{2}$ was not supported (see Table 4). 
Table 4 also shows the effect size $\left(\mathrm{f}^{2}\right)$ as suggested by Cohen (2012) which were 0.020 for Innovativeness and EPP, 0.012 for pro-activeness and EPP as well as 0.033 for risk taking and EPP which showed small effect sizes for innovativeness and risk taking with no effect for pro-activeness. Furthermore, in line with the suggestion made by Dawson (2014), interaction effects were plotted to determine how EPP (moderator) changes the relationship between innovativeness, pro-activeness, risk taking and internationalization.

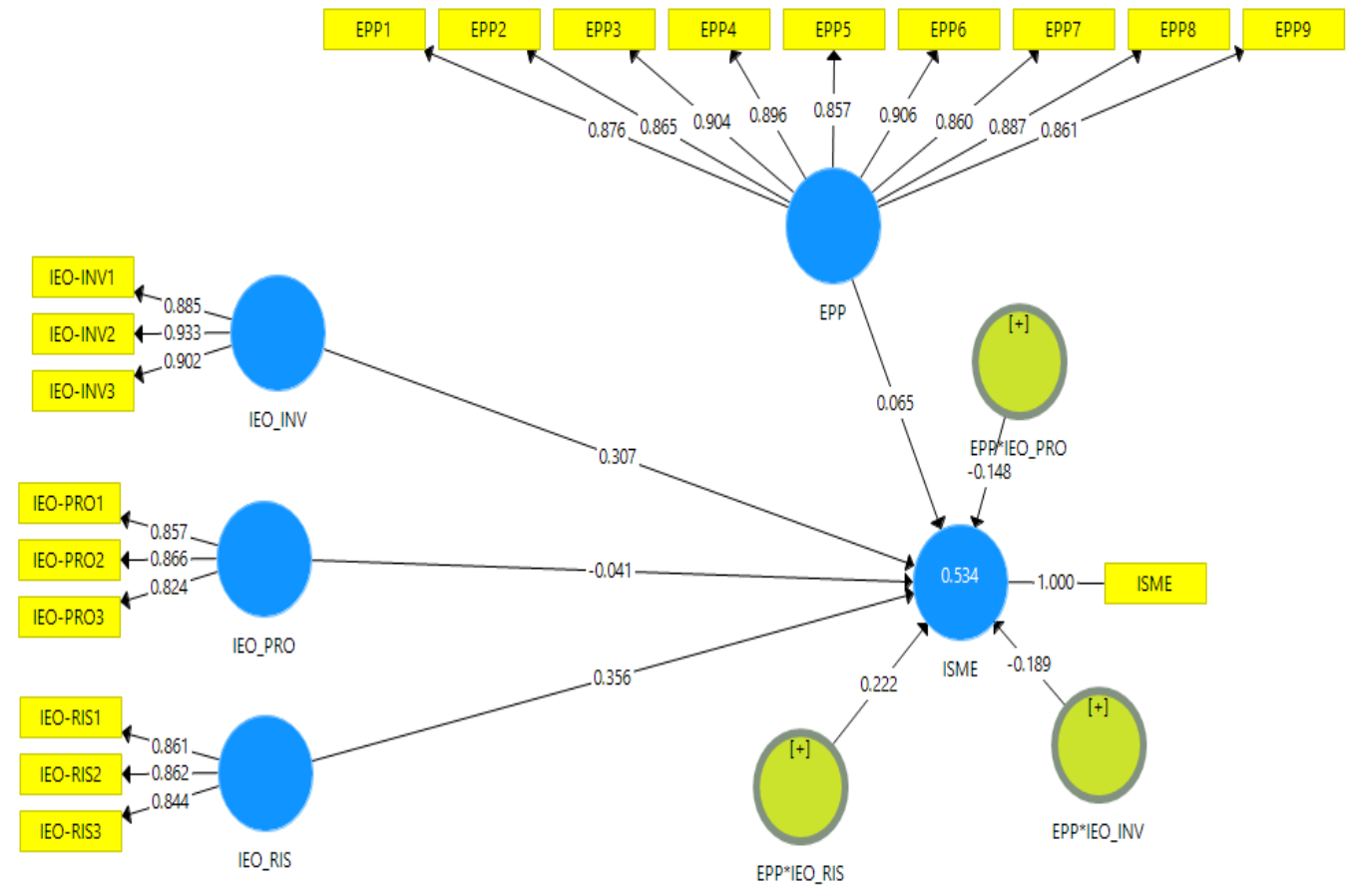

Figure 2. Path model showing beta values in the relationships between IEO, EPP and Internationalization of SMEs

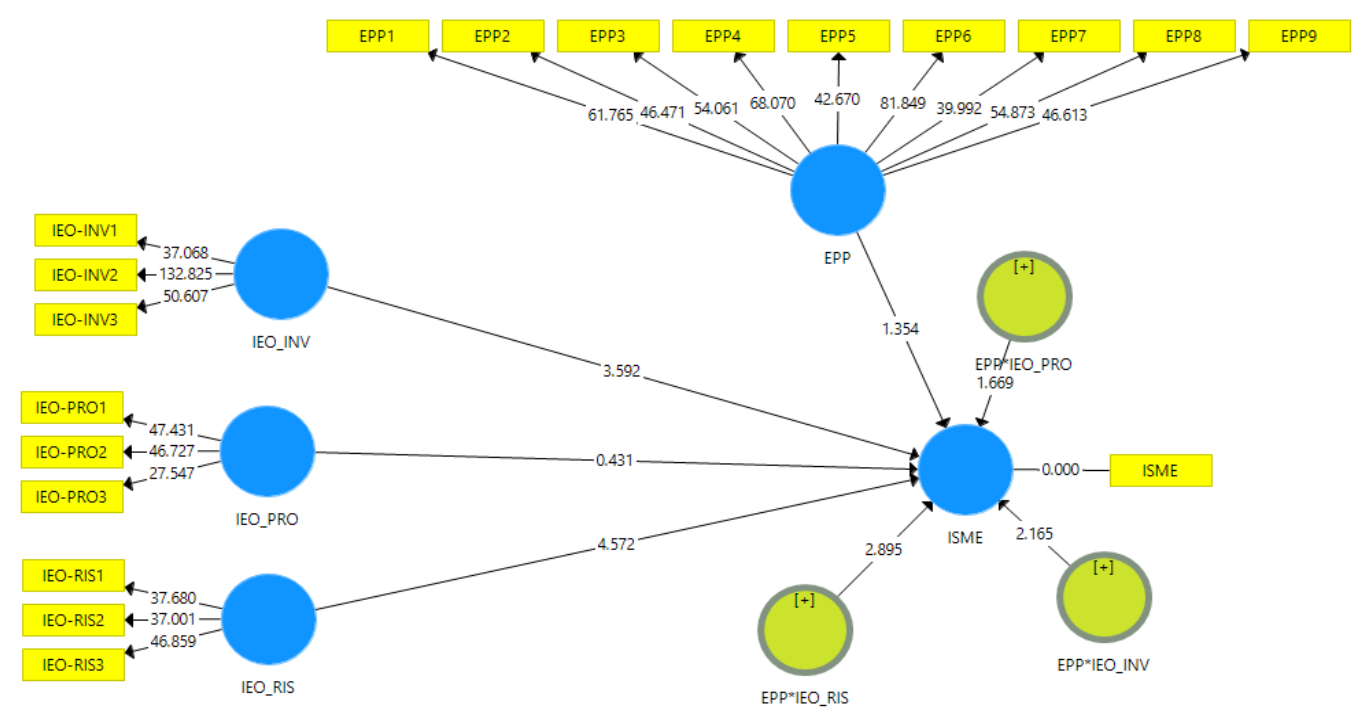

Figure 3. Bootstrapping Of Path Coefficient Of International Entrepreneurial Orientation, Export Promotion Programs And Internationalization Of Smes 
Table 4. Testing Hypothesis

\begin{tabular}{llll}
\hline & \multicolumn{3}{c}{ Dependent= ISMEs } \\
\hline & & Std Beta & Std Beta \\
\hline IEO-INV & Effect size & Main Effect & Interaction Effect \\
IEO-PRO & 0.046 & $0.307^{* * *}$ & $0.085^{* * *}$ \\
IEO-RIS & 0.001 & -0.041 & 0.096 \\
Export Promotion Programs (EPP) & 0.088 & $0.356^{* * *}$ & $0.08^{* * *}$ \\
EPP* IEO-INV & 0.008 & -0.148 & 0.049 \\
EPP* IEO-PRO & 0.016 & & $0.086^{*}$ \\
EPP* IEO-RIS & 0.012 & & 0.087 \\
$\mathrm{R}^{2}$ & & & $0.074^{* *}$ \\
$\mathrm{Q}^{2}$ & 0.033 & & \\
\hline${ }^{2}$ & & & \\
\hline
\end{tabular}

Note: $* * * \mathrm{p}<0.01, * * \mathrm{p}<0.05, * \mathrm{p}<0.1, \mathrm{f} 2$ of $0,02,0.15$ and 0.35 are interpreted to be small, medium and large size effects respectively. IEO-International Entrepreneurial Orientation, EPP-Export Promotion Programs, INV-Innovativeness, PRO-Pro-activeness, RIS-Risk taking

The interaction plot in Figure 4 shows that IEO-Innovativeness and internationalization relationship was significant with negative effect. At higher levels of EPP, innovativeness was lower indicating reverse impact on internationalization. Figure 5 indicates export promotion program did not have any impact on the relationship between IEO-Pro-activeness and internationalization of SMEs. However, in Figure 6 the relationship between IEO Risk-taking was stronger with high EPP while there was no impact on the relationship with low EPP.

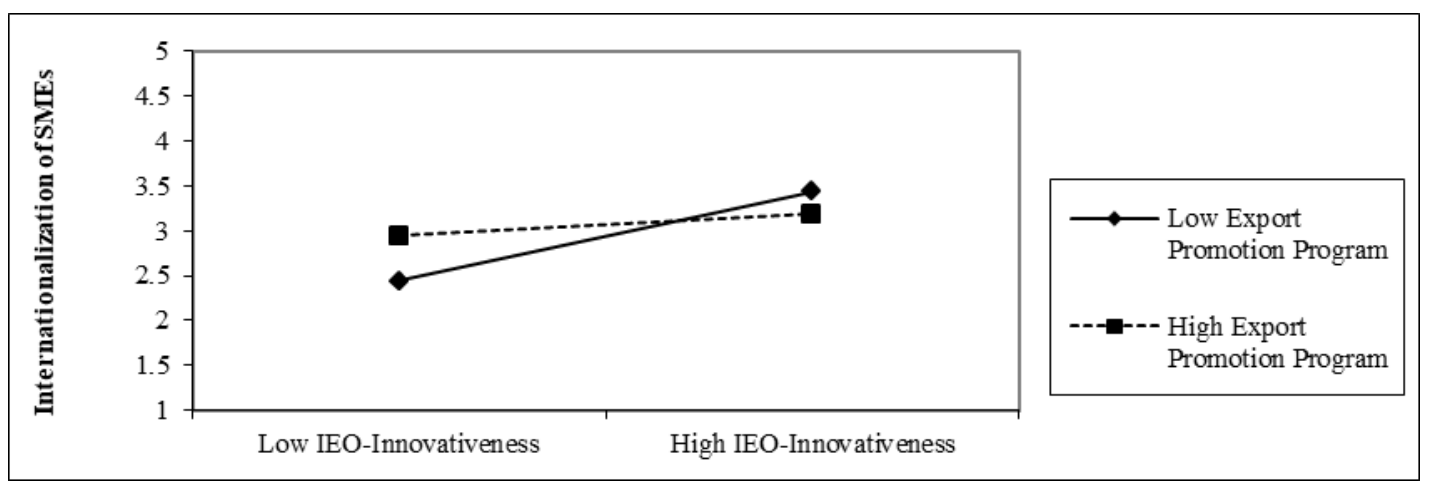

Figure 4. Interaction Plot Showing Moderating Effect Of Export Promotion Program On The IEO-Innovativeness-Internationalization Of Smes Relationship

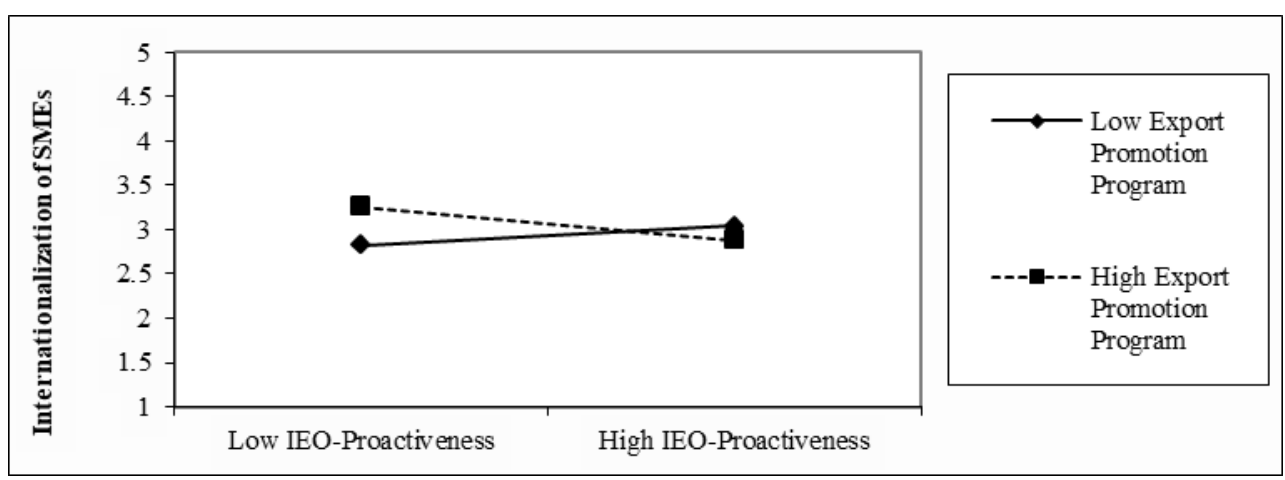

Figure 5. Interaction plot showing moderating effect of export promotion program on the IEO- Pro-activeness Internationalization of SMEs relationship 


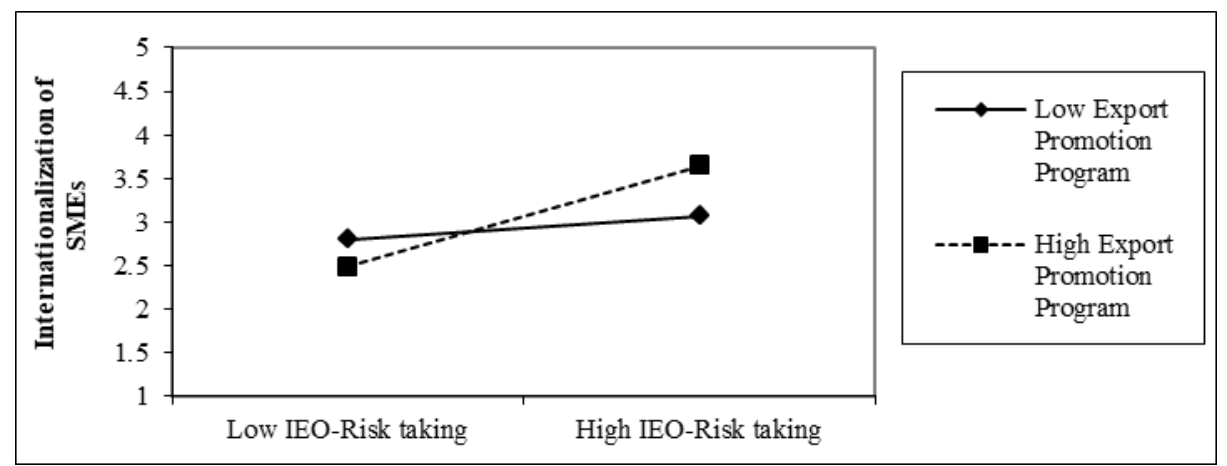

Figure 6. Interaction plot showing moderating effect of export promotion program on the IEO-Risk takingInternationalization of SMEs relationship

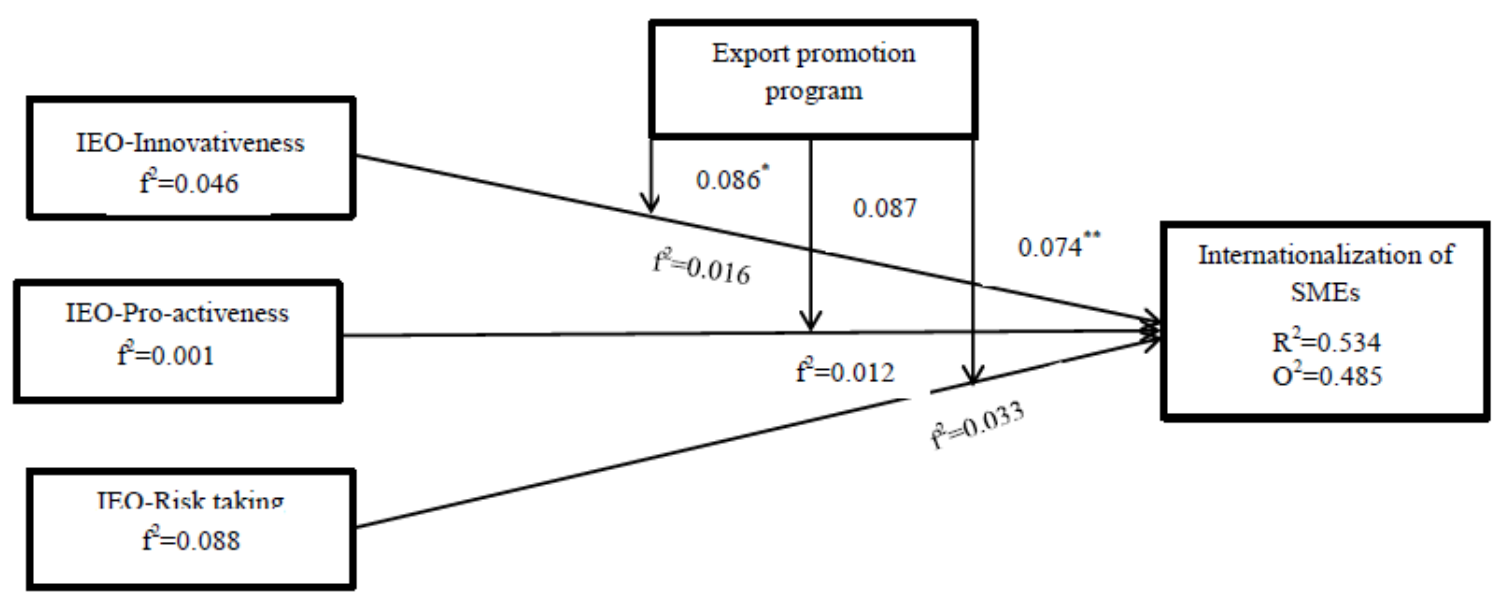

Figure 7. Framework showing interaction beta values, f2, R2, and Q2,

Figure 7 shows the beta values of the interaction model. It also indicates the effect sizes of all the predictors and the interaction variable as well as the $\mathrm{R}^{2}$ and the predictive relevance of the endogenous construct.

\section{Implications and Conclusion}

\section{IMPLICATIONS FOR THEORY}

This study extends institutional and dynamic capability theories. The former is extended by examining the supportive role of government and institutions in capacity building for SMEs to enhance their competitive positions in global value chain through policies of favorable market incentives and creation of new ventures (Hsu, Chen \& Cheng, 2013). The latter is stretched by employing export support programs through integrating and configuring firms' managerial, innovative and relational resources to enhance the performance of SMEs' by promoting IEO to achieve international market competitiveness.

The fact that IEO has been a strategic construct in managerial successes in internationalization, this study developed a framework with its dimensions; innovativeness, pro-activeness and risk taking, to ascertain the extent of impact each dimension makes on internationalization of SMEs when interacted with export promotion programs (EPPs) as a moderator. The analysis in the current research context reveals that SMEs have potential of being innovative at all levels of EPPs while firms' pro-activeness might not be affected by either high or low EPPs. In the case of risk-taking, however, higher EPPs improves the risk perception of managers of firms (Leonidou, Constantine, \& Piercy, 1998: Leonidou et al., 2011) and hence enable SMEs to engage in international transactions in uncertain environments. This result reflect on previous findings that firms with higher risk taking propensity have shown better performance in export and risk taking was also found to moderate the relationships with SMEs export performance (Okpara \& Okpara, 2009). From the inception of SMEs, the decision to internationalize has been found to be related positively to risk taking (Kropp, Lindsay, \& Shoham, 2008). Similarly, Taylor (2013) found that the relationships between internationalization process and internationalization activity of exporting and risk taking were positive. 
Assessing the effect of EPPs on each dimension of IEO is also an extension of knowledge component of internationalization theory with regards to enhancing entrepreneurial decision making (Lumpking \& Dess, 1996). It brings to light how the IEO dimensions interact with EPPs to give varied outcomes which add to literature insights on such variation at different levels of moderator-antecedent interactions. If the IEO dimensions were aggregated into a single measure as done in previous studies, such independent effect could not be determined (Jantunen, 2005). Thus, this investigation of IEO dimensions as antecedents of SMEs internationalization extends the literature of international entrepreneurship.

\section{IMPLICATIONS FOR PRACTIONERS AND POLICY MAKERS}

This study could be a guide to designing policies regarding contents of EPPs. Managers of enterprises could develop their entrepreneurial skills for effective decision making by carefully appraising the contents of EPPs and selecting specific programs that will enhance their managerial capacity and support their internationalization efforts. Policy makers especially, within the government, need to identify those EPPs component that will effectively impact on firms' entrepreneurial development. This can easily be achieved through assessment of training needs of the firms and support them in areas of weaknesses. Such support should consider important components of EPPs and their implications in the program contents. The program should be able to develop entrepreneurial skills to cover managerial, innovativeness, risk taking and pro-active skills in achieving efficient internationalization.

The study also guides the policy makers on the success and weaknesses of the EPPs. As the findings in the current study demonstrate that participation in EPPs has significantly affected innovativeness and risk taking's outcomes on internationalization, the policy makers must enhance and develop the delivery pattern of the program. The outcome of this study further indicates the need for government's commitment in supporting SMEs to internationalize by developing export assistance programs to create an opportunity for firms to have access to foreign markets and other stakeholders abroad.

\section{CONCLUSION AND FUTURE RESEARCH}

Based on the moderation results, evidence is presented on the influence of EPPs on the relationships between IEO dimensions and internationalization of SMEs. The study also provides evidences from previous studies on how specific components of EPPs enhance the dimensions of IEO to achieve SME internationalization success. This study further adds some insights on internationalization by identifying how EPPs affect IEO dimensions towards successful internationalization of SMEs in a way previous studies have less considered. These, therefore, add to the knowledge of adoption of EPPs in the process of managerial skill enhancement and export development.

Future research can extend this work by using the specific EPP components in moderating the IEO dimensions to ascertain their specific effects on each of the antecedents. This study also recommends that further studies look at SMEs based on their industry to determine how interactions can vary with the type of industry being investigated.

\section{References}

Ajayi, B. (2016). Capabilities on the Export Performance of Nigerian Agricultural SMEs. Journal of Entrepreneurship and Innovation in Emerging Economics, 2(1), 1-23. https://doi.org/10.1177/2393957515619720

Balabanis, G. I., \& Katsikea, E. S. (2003). Being an entrepreneurial exporter: does it pay? International Business Review, 12(2), 233-252. https://doi.org/10.1016/S0969-5931(02)00098-7

Boso, N., Story, V. M., Cadogan, J. W., \& Ashie, E. (2015). Complementary effects of entrepreneurial orientation, market orientation and network ties on performance of entrepreneurial firms in a developing economy. In Springer (pp. 268-268). https://doi.org/10.1007/978-3-319-10951-0_95

Boso, N., Story, V. M., \& Cadogan, J. W. (2013). Entrepreneurial orientation, market orientation, network ties , and performance: Study of entrepreneurial firms in a developing economy. Journal of Business Venturing, 28, 708-710. https://doi.org/10.1016/j.jbusvent.2013.04.001

Cohen, J. (2012). Using Effect Size-or Why the P Value Is Not Enough, (September), 279-282. https://doi.org/10.4300/JGME-D-12-00156.1

Coviello, N. E., Mcdougall, P. P., \& Oviatt, B. M. (2011). The emergence, advance and future of international entrepreneurship research - An introduction to the special forum. Journal of Business Venturing, 26(6), 625-631. https://doi.org/10.1016/j.jbusvent.2011.07.002 
Covin, J. G., \& Miller, D. (2013b). International Entrepreneurial Orientation: Conceptual Considerations, Research Themes, Measurement Issues, and Future Research Directions. Entrepreneurship Theory and Practice Entrepreneurship Research, 38(1), 11-14. https://doi.org/10.1111/etap.12027

Covin, J. G., \& Sleven, D. P. (1989). Strategic management of small firms in hostile and benign environments. Strategiic Management Journal, 10(March 1988), 75-87. https://doi.org/10.1002/smj.4250100107

Dai, L., Maksimov, V., Gilbert, B. A., \& Fernhaber, S. A. (2014). Entrepreneurial orientation and international scope: The differential roles of innovativeness, proactiveness, and risk-taking. Journal of Business Venturing, 29(4), 511-524. https://doi.org/10.1016/j.jbusvent.2013.07.004

Daniel, S. (1993). Measuring the degree of internationalization of a firm Daniel Sullivan University of Delaware Abstract . In spite of both positivistic and instrumental research, the reliability of measuring the degree of internationalization of a firm remains speculat, (October), 325-342. https://doi.org/10.1057/palgrave.jibs.8490203

Daszkiewicz, N., \& Wach, K. (2012). Internationalizationof SMEs contexts, model and implimenttion. Gdańsk university of technology publishers.

Dawson, J. F. (2014). Moderation in Management Research: What, Why, When, and How. Journal of Business and Psychology, 29(1), 1-19. https://doi.org/10.1007/s10869-013-9308-7

Durmu, S. S., Apfelthaler, G., Zamantili, D., Alvarez, R., \& Mughan, T. (2012). The effect of government-designed export promotion service use on small and medium-sized enterprise goal achievement: A multidimensional view of export performance. Industrial Marketing Management, 41, 680-691. https://doi.org/10.1016/j.indmarman.2011.09.016

Felzensztein, C., Ciravegna, L., Robson, P., \& Amorós, E. (2015). The international strategy of Latin American SMEs: the effects of networks and entrepreneurship orientation. J Small Bus Manag, 53(51), (S1), 145-160. https://doi.org/10.1111/jsbm.12188

Fink, M., Harms, R., \& Kraus, S. (2008). Cooperative internationalization of SMEs : Self-commitment as a success factor for International Entrepreneurship. European Management Journal, 26(6), 429-440. https://doi.org/10.1016/j.emj.2008.09.003

Lumpkin, G. T., \& Dess, G. G. (1996). Clarifying the entrepreneurial orientation construct and linking it to performance. Academy of management Review, 21(1), 135-172. https://doi.org/10.2307/258632

Gençtürk, E. F., \& Kotabe, M. (2001). The Effect of Export Assistance Program Usage on Export Performance : Journal of International Marketing, 9(2), 51-72. https://doi.org/10.1509/jimk.9.2.51.19886

Griffith, D. A., \& Czinkota, M. R. (2012). Release the constraints : Solving the problems of export financing in troublesome times. Business Horizons, 55(3), 251-260. https://doi.org/10.1016/j.bushor.2012.01.003

Haddoud, M. Y., Jones, P., \& Newbery, R. (2017). Export promotion programmes and SMEs' performance. Journal of Small Business and Enterprise Development, 24(1), 68-87. https://doi.org/10.1108/JSBED-07-2016-0116

Hair, J. F., Sarstedt, M., Hopkins, L., \& Kuppelwieser, V. G. (2014). Partial least squares structural equation modeling (PLS-SEM). Sage Publisher (Vol. 26). https://doi.org/10.1108/EBR-10-2013-0128

Henseler, J., Ringle, C. M., \& Sarstedt, M. (2015). A new criterion for assessing discriminant validity in variance-based structural equation modeling, 115-135. https://link.springer.com/article/10.1007\%252Fs11747-014-0403-8

Hermannsdottir, A. (2008). Theoretical Underpinnings of the Internationalization Process. Institute of Business research.

Hsu, W. T., Chen, H. L., \& Cheng, C. Y. (2013). Internationalization and firm performance of SMEs: The moderating effects of CEO attributes. Journal of World Business, 48, 1-12. https://doi.org/10.1016/j.jwb.2012.06.001

Jantunen, A. R. I. (2005). Entrepreneurial Orientation, Dynamic Capabilities and International Performance, 223-243. https://doi.org/10.1007/s10843-005-1133-2

Javalgi, R. G., \& Todd, P. R. (2011). Entrepreneurial orientation, management commitment, and human capital: The internationalization of SMEs in India. Journal of Business Research, 64(9), 1004-1010. https://doi.org/10.1016/j.jbusres.2010.11.024 
Johanson, J. (1990). The Mechanism of Internationalisation. International Marketing Review, 7(4), 1-63. https://doi.org/10.1108/02651339010137414

Johanson and Vahlne. (1977). The internationalization process of the firm-a model of knowledge development and increasing foreign market commitments. Journal of International Business Studie, 8(1), 23-32. https://doi.org/10.1057/palgrave.jibs.8490676

Jones, M. V., \& Coviello, N. E. (2005). Internationalisation: conceptualizing an entrepreneurial process of behaviour in time. Journal of International Business Studies, 36, 284-303. https://doi.org/10.1057/palgrave.jibs. 8400138

Jones, P., \& Newbery, R. (2017). Export promotion programmes and SMEs 'performance Exploring the network promotion role. Retrieved from https://www.emerald.com/insight/content/doi/10.1108/JSBED-07-2016-0116/full/html?fullSc=1

Joseph F. Hair, J., Hult, G. T. M., Ringle, C. M., \& Rstedt, M. S. (2017). Partial least squares structural equation modeling (PLS-SEM). European Business Review. Washington DC: SAGE publihers.

Kaleka, A. (2002). Resources and capabilities driving competitive advantage in export markets: guidelines for industrial exporters, 31, 273-283. https://doi.org/10.1016/S0019-8501(00)00148-6

Khalili, H., Nejadhussein, S., \& Fazel, A. (2013). The influence of entrepreneurial orientation on innovative performance Study of a petrochemical company in Iran. Journal of Knowledge-Based Innovation in China, 5(3), 262-278. https://doi.org/10.1108/JKIC-09-2013-0017

Kibler, E., \& Kautonen, T. (2016). I S B J The moral legitimacy of entrepreneurs: An analysis of across 26 countries. Retrieved from https://journals.sagepub.com/doi/abs/10.1177/0266242614541844

Knight, G. A. (2001). Entrepreneurship and strategy in the international SME. Journal of International Management, 7(3), 155-171. https://doi.org/10.1016/S1075-4253(01)00042-4

Knight, G. A., Kim, D., \& Knight, G. A. (2015). International business the contemporary competence firm and, 40(2), 255-273. https://doi.org/10.1057/palgrave.jibs. 8400397

Kropp, F., Lindsay, N. J., \& Shoham, A. (2008). Entrepreneurial orientation and international entrepreneurial business venture startup. International Journal of Entrepreneurial Behavior \& Research, 14(2), 102-117. https://doi.org/10.1108/13552550810863080

Kuivalainen, O., Sundqvist, S., \& Servais, P. (2007). Firms' degree of born-globalness, international entrepreneurial orientation and export performance. Journal of World Business, 42, 253-255. https://doi.org/10.1016/j.jwb.2007.04.010

Kumar, V., \& Singh, N. 2008. Internationalization and Performance of Indian Pharmaceutical Firms. Published Online in Wiley InterScience, 50(5), 321-330. https://onlinelibrary.wiley.com/doi/abs/10.1002/tie.20217

Leonidou, L. C., Constantine, S., \& Piercy, N. F. (1998). Identifying Managerial Influences on Exporting: Past Research and Future Directions. Journal of International Marketing, 6(2), 74-102. https://doi.org/10.1177/1069031X9800600209

Leonidou, L. C., Palihawadana, D., \& Theodosiou, M. (2011). National Export-Promotion Programs as Drivers of Organizational Resources and Capabilities: Effects on Strategy. Journal of International Marketing, 19(2), 1-29. https://doi.org/10.1509/jimk.19.2.1

Leonidou, L. C., \& Theodosiou, M. (2004). The export marketing information system: an integration of the extant knowledge. Journal of World Business, 39, 12-36. https://doi.org/10.1016/j.jwb.2003.08.005

Mbura, J., \& Rutashobya, L. (2004). Serendipitous Networking Dynamics and Internationalization of Agroprocessing Firms in Tanzania. International Journal of Social Economics, 31(1/2), 1-36. https://doi.org/10.1108/03068290410515484

Miller, D., \& Le Breton-Miller, I. (2011). Governance, social identity, and entrepreneurial orientation in closely held public companies. Entrepreneurship: Theory and Practice, 35(5), 1051-1076. https://doi.org/10.1111/j.1540-6520.2011.00447.x

Morgan, N. A., Vorhies, D. W., \& Schlegelmilch, B. B. (2006). Resource - performance relationships in industrial export ventures: The role of resource inimitability and substitutability. Industrial Marketing Management, 35, 621-633. https://doi.org/10.1016/j.indmarman.2005.05.018

North, D. C. (2016). Institutions and Economic Theory. The American Economist, 36(1), 72-76. 
https://doi.org/10.1177/0569434516630194

Okpara, J. O., \& Okpara, J. O. (2009). Strategic choices, export orientation and export performance of SMEs in Nigeria. https://doi.org/10.1108/00251740910984541

Oviatt, B. M., \& Mcdougall, P. P. (2005). The internationalization of entrepreneurship. Journal of International Business Studies, 36, 2-8. https://doi.org/10.1057/palgrave.jibs.8400119

Owusu-frimpong, N., \& Martins, A. (2010). Adoption and Implementation of Internal Marketing Systems by Ghanaian Small- and Medium-Sized Enterprises. Journal of African Business, 11(1), 26-48. https://doi.org/10.1080/15228910903187999

Henseler, J., Ringle, C. M., \& Sarstedt, M. (2016). Testing measurement invariance of composites using partial least squares. International marketing review. https://doi.org/10.1108/IMR-09-2014-0304

Ripollés-Meliá, M., Menguzzato-Boulard, M., \& Sánchez-Peinado, L. (2007). Entrepreneurial orientation and international commitment. Journal of International Entrepreneurship, 5(3-4), 65-83. https://doi.org/10.1007/s10843-007-0016-0

Roper, S., Vahter, P., \& Love, J. H. (2013). Externalities of openness in innovation. Research Policy, 42(9), 1544-1554. https://doi.org/10.1016/j.respol.2013.05.006

Sambharya, R., \& Musteen, M. (2014). Institutional environment and entrepreneurship: An empirical study across countries. Journal of International Entrepreneurship, 12(4), 314-330. https://doi.org/10.1007/s10843-014-0137-1

Shamsuddoha, A. \& N. (2012). Impact of government export assistance on internationalization of SMEs from developing nations. Journal of Enterprise Information Management, 22(4), 408-422. https://doi.org/10.1108/17410390910975022

Shamsuddoha, A. K., \& Ali, M. Y. (2006). Mediated effects of export promotion programs on firm export performance. Asia Pacific Journal of Marketing and Logistics, 18(2), 93-110. https://doi.org/10.1108/13555850610658255

Simonin, B. L. (1997). No Title The importance of collaborative know-how: An empirical test of the learning organization. Academy of Management Journal, 40(5), 1150-1174. https://doi.org/10.2307/256930

Sraha, G., \& Sraha, G. (2015). Public policy makers Improving export promotion programmes emerging economy. https://doi.org/10.4018/978-1-4666-8358-7.ch036

Sun, S. L., Peng, M. W., Lee, R. P., \& Tan, W. (2015). Institutional open access at home and outward internationalization. Journal of World Business, 50(1), 234-246. https://doi.org/10.1016/j.jwb.2014.04.003

Sundqvist, S., Kyläheiko, K., Kuivalainen, O., \& Cadogan, J. W. (2012). Kirznerian and Schumpeterian entrepreneurial-oriented behavior in turbulent export markets. International Marketing Review, 29(2), 203-219. https://doi.org/10.1108/02651331211216989

Szyliowicz, D., \& Galvin, T. (2010). Applying broader strokes: Extending institutional perspectives and agendas for international entrepreneurship research. International Business Review, 19(4), 317-332. https://doi.org/10.1016/j.ibusrev.2010.01.002

Taylor, P. (2013). The effect of entrepreneurial orientation on the internationalization of SMEs in developing countries. African Journal of Business Management, 7(19), 1927-1937.

Vrande, V. Van De, Jong, J. P. J. De, \& Vanhaverbeke, W. (2009). Open innovation in SMEs : Trends , motives and management challenges, 29, 423-437. https://doi.org/10.1016/j.technovation.2008.10.001

Yoeh, P. L. (2004). International learning: antecedents and performance implications among newly internationalizing companies in an exporting context. International Marketing Review, 31(4/5), 511-535. https://doi.org/10.1108/02651330410547171 


\section{APPENDIX}

IEO

Innovativeness

1. The top management of our firm place importance on research and development, technological leadership, and innovations

2. Our firm introduced new lines of products/services since its establishment

3. There have frequent changes in products/ service lines in our firm

Pro-activeness

1. My firm comes up with new ways/products which our competitors imitate

2. My firm very often the first business to introduce new products/ services, administrative techniques, operating technologies etc.

3. My firm engage in competitive activities with other firms

Risk-taking

1. The management of my firm take low risk project with normal and certain returns

2. Due to the nature of business environment, the management of my firm take gradual and incremental behavior to achieve firm's objectives

3. In decision-making, my firm wait to see the decisions of other firms in order to minimize the chances of making costly decisions

\section{EXPORT PROMOTION PROGRAMS}

1. Information about foreign market opportunities

2. Specific information about doing business with a particular firm

3. General information about doing business in a specific country

4. Provision of marketing information/advice

5. Organization of export seminars/conferences

6. Training programs specializing in exporting

7. Training on export documentation

8. Assistance in participating in trade shows/exhibitions

9. Participation in trade missions in foreign markets

10. Support by trade offices abroad

\section{INTERNATIONALIZATION OF SMES}

1. Percentage of foreign sales to total sales

\section{Copyrights}

Copyright for this article is retained by the author(s), with first publication rights granted to the journal.

This is an open-access article distributed under the terms and conditions of the Creative Commons Attribution license (http://creativecommons.org/licenses/by/4.0/). 